\title{
The potential of aroma textiles in North-East Romania
}

DOI: $10.35530 / I T .070 .05 .1621$

ANGELA DANILA

VLAD ROTARU

EMIL IOAN MUREŞAN

ALINA POPESCU

\author{
ABSTRACT - REZUMAT
}

\section{The potential of aroma textiles in North-East Romania}

In the last years in the textile industry there is a tendency of orientation towards products with added value. Recent research in the field has shown that the field of aroma therapeutic products is constantly growing due to their advantages: they are environmentally friendly and have beneficial effects on human health and well-being feeling. The present work aims to test the degree of acceptance and potential of aroma textiles (antimicrobial patches, flavoring sheets, anti-cellulite tights and flavoring sportswear) on the market. This research is a market study and comprises two studies: frequency analysis for each variable (22 variables were selected) and verification of working hypotheses (4 hypotheses were chosen) by analysis of variance - One-way ANOVA method. As a quantitative research method, the survey was used and a questionnaire with 26 questions as methodological tool was used. The results of this survey are based on the information provided by the respondents from North-East Romania. The answers included in the survey reflect what the respondents stated. In this study, the following significant aspects were highlighted: high confidence in aroma therapeutic products; the Romanians increasingly prefer textile products with added value, for their health benefits; most interviewees are willing to pay more for textile products with a relaxing effect.

Keywords: survey, frequency analysis, analysis of variance, antibacterial patches, flavoring sheet, flavoring sportswear

\section{Potențialul aromotextilelor în nord-estul României}

În ultimii ani în industria textilă, există o tendință de orientare către produsele cu valoare adăugată. Cercetări recente au arătat că domeniul produselor aromoterapeutice este în continuă creștere datorită avantajelor pe care le prezintă: sunt ecologice și au efecte benefice asupra sănătătii și stării de bine. Scopul acestei lucrări este de a testa gradul de acceptare și potențialul aromotextilelor (plasturi antimicrobieni, cearșafuri cu efect aromatizant, colanți anticelulitici și îmbrăcăminte sport cu efect aromatizant) pe piață. Cercetarea realizată în cadrul lucrării reprezintă un studiu de piață și cuprinde 2 studii: analiza frecvenței pentru fiecare variabilă (22 de variabile) și verificarea ipotezelor de lucru (4 ipoteze) prin analiza de varianță unidirecțională (ANOVA). Ca metodă de cercetare cantitativă s-a utilizat sondajul, iar un chestionar (26 întrebări) a fost utilizat ca instrument metodologic. Rezultatele sondajului sunt bazate pe informațiile furnizate de respondenții din nord-estul României. Răspunsurile incluse în sondaj reflectă ceea ce au declarat respondentiii. În acest studiu, au fost evidențiate următoarele aspecte semnificative: încredere ridicată în produsele aromoterapeutice; românii preferă din ce în ce mai mult produsele textile cu valoare adăugată, pentru beneficiile pe care le prezintă pentru sănătate; cei mai mulți dintre cei intervievați sunt dispuși să plătească mai mult pentru produse textile cu efect relaxant.

Cuvinte-cheie: sondaj, analiza frecvenței, analiză de varianță, plasturi antimicrobieni, cearșafuri cu efect aromatizant, îmbrăcăminte sport cu efect aromatizant

\section{INTRODUCTION}

For the first time, cosmeto-textile concept appeared in 1980 in Japan and at present, cosmeto-textiles is one of the most competitive and dynamic areas of research worldwide and is based on the incorporation of active substances into textiles [1, 2]. The Cosmeto-textile is a technology that merges the cosmetics and the textiles worlds through advanced methods using cyclodextrins, microencapsulation techniques or nanotechnology [3]. In recent years, the number of companies producing cosmeto-textiles and the number of active ingredients incorporated into textile materials is constantly increasing. At present there are a number of textile products in the market with cosmetic properties (moisturizing, slimming, energizing, refreshing, relaxing, vitalizing and
UV protection) [4]. Because textile materials can act as a delivery system, they can be useful for in vivo applications [5]. Often, a cosmeto-textile offers more than an improved comfort, but also a treatment for various skin diseases (supported textiles for venous insufficiency, antibacterial clothing, antioxidant textiles, etc.) [6]. The advantage of using a textile material with cosmetic role is given by the ease of application, replacing the application in the form of ointments / creams / lotions / etc.

In the category of cosmeto-textiles, an important role is played by aroma textiles. In recent years, more and more people come into contact with aroma therapeutic textile materials obtained by applying the essential oils on textile supports.

Essential oils are volatile and they rapidly evaporate from surfaces. From this reason, their embedding in 
suitable shell allows minimizing the evaporation and protecting the oil from high temperature, oxidation and UV light [7, 8]. Most essential oils are used to provide antimicrobial effect to textile support [9]. Most often, in the specialty literature, the essential oils of lemon, chamomile, rose, cinnamon, garlic and jasmine are mentioned [10].

For this study aroma textiles obtained by incorporation four types of essential oils (Thyme essential oil, Lavender essential oil, Mint essential oil and Rosemary essential oil) in different embedding matrices were used. The aim of the research was to evaluate the degree of acceptance and the potential of aroma textiles in north-east Romania.

\section{AROMA TEXTILES ANALYZED IN MARKETING STUDY}

Aroma textile materials (antibacterial patches, flavoring sheet, flavoring sportswear and anti-cellulite tights) for which were analyzed the degree of acceptance on the market were obtained by applying essential oils produced by DOĞAL DESTEK company, Turkey (Rosemarinus Officinalis, Origanum Onites, Mentha Piperita and Lavandula Anguntifolia), in the form of microcapsules or O/W emulsions, at the surface level [11].
GOAL AND OBJECTIVE OF MARKETING STUDY

This study aims to test the degree of acceptance and the potential of aroma textiles on the market from North-East Romania and consumers' preference in choosing a certain type of aroma textile.

Objectives of the study:

- Determining the intention to purchase aroma textile products;

- Determining the purchase frequency of aroma textile products;

- Identification of the selection criteria for an aroma textile product;

- Identification of preferences to a particular type of aroma textile;

- Assessing the amount that potential consumers are willing to spend to buy an aroma textile product.

\section{THE VARIABLES OF THE STUDY}

This research is a market study and comprises two studies.

Study 1: Frequency analysis for each variable

Study 2:

Hypothesis 1: Employment status influences the openness to the use of aroma textiles;

Hypothesis 2: Age influences the type of choosen product;

Hypothesis 3: Gender influences the criteria for choosing a product;

Table 1

\begin{tabular}{|c|c|c|c|}
\hline \multicolumn{4}{|c|}{ THE ANALYZED VARIABLES } \\
\hline No. & Study 1 & No. & Study 2 \\
\hline 1 & Notoriety of aroma therapeutic products & & Dependent variables: \\
\hline 2 & Purchase frequency & 1 & Openness to aroma textile products \\
\hline 3 & The advantages of using aroma textiles & 2 & Preferred product type \\
\hline 4 & Preferred type of aroma therapeutic product & 3 & Criteria for choosing an aroma textile product \\
\hline 5 & Order of antimicrobial patch preference over other products & 4 & Quality \\
\hline 6 & Order of flavoring sheet preference over other products & 5 & Price \\
\hline 7 & Order of flavoring sportswear preference over other products & 6 & Design \\
\hline 8 & Order of anti-cellulite tights preference over other products & 7 & Advertising \\
\hline 9 & Criteria for the selection of aroma textile products & & Independent variables: \\
\hline 10 & The importance of the price indicator & 1 & Employment status \\
\hline 11 & The importance of the quality indicator & 2 & Age \\
\hline 12 & The importance of the design indicator & 3 & Gender \\
\hline 13 & The importance of the publicity indicator & & \\
\hline 14 & The degree of promotion of aroma textile products & & \\
\hline 15 & The price of an antimicrobial patch & & \\
\hline 16 & The price of a flavoring sheet & & \\
\hline 17 & The price of a flavoring sportswear & & \\
\hline 18 & The price of a pair of anti-cellulite tights & & \\
\hline 19 & Gender & & \\
\hline 20 & Age & & \\
\hline 21 & Employment status & & \\
\hline 22 & Income & & \\
\hline
\end{tabular}


Hypothesis 4: The indicators: quality, price, design and advertising, are influenced by employment status.

Variables used in both studies are presented in table 1.

\section{RESEARCH METHODOLOGY}

Quantitative research method used in this study is survey and the questionnaire was used as a methodological tool. The questionnaire (consists of 26 questions) was created as a form in Google Forms (Google Inc.) and was applied from January to August 2019 in lassy. The results of the questionnaire were processed using the SPSS 18 program [12]. The advantages that support the efficiency of the chosen method are: facilitating the extraction of the individuals under study, a low cost and a time to determine the sample, the possibility of a rigorous control of the data collection process. In order to avoid the halo effect (the tendency to respond the same to several questions), a light presentation of the questionnaire was chosen without delimiting by titles the category or dimensions pursued by the question. The sampling method was established using the simple random sampling method, each individual (over 18 years of age) having the possibility to be included in the sample. Questionnaires were mailed out to randomly selected addresses from lassy region.

\section{INVESTIGATED GROUP}

The investigated group was composed of 65 people with different employment status (figure 1). All respondents come from urban areas and are between 20 and 68 years old (figure 2).

\section{RESULTS ANALYSIS}

\section{Study 1}

In order to carry out this study, the method of calculating frequencies in percentages was used. The following are the most important results from the frequency analysis.

Most of the interviewees had heard about the aroma therapeutic products. The results show that $60 \%$ of them have heard of the aroma textiles and $40 \%$ do not know this kind of products. Majority of the respondents have not bought so far aroma textiles, the reasons being different (either the lack of knowledge of this market or the fear of being disappointed with this kind of products). Thus $63.1 \%$ of them has not bought so far aroma therapeutic products, but are interested in them, the same percentage of respondents rarely and never buy aroma therapeutic products (16.9\%) and only $3.1 \%$ of them frequently buy aroma therapeutic textile products. According to a study conducted by the company iSense Solutions, the Romanians' concern about adopting a healthy lifestyle becomes an important one [13]. This fact also results from our study: $66.2 \%$ of the respondents have chosen aroma textiles for their health benefits.

By analyzing variables no. 4-8 we wanted to know which of the four aroma therapeutic products is preferred by those interviewed and which is the order of preferences. Based on the received responses it is observed that the interviewees' preferences decreases in the order: antibacterial patches, sportswear with a flavoring effect, flavoring sheet, anti-cellulite tights. $33.85 \%$ of the respondents placed the antibacterial patch in the first place, $26.15 \%$ of them placed flavoring sportswear on the first place, $24.62 \%$ of the respondents placed the anti-cellulite tights in the first place and $15.38 \%$ of them placed the anti-cellulite tights in the first place.

Analysis of the criterion for choosing aroma textiles has shown that $76.9 \%$ of the interviewees choose products by its quality. From analyzing the preference order of criterion for aroma textiles choice it turned out that $73.8 \%$ of the interviewees put the quality indicator in the first place, $20 \%$ of them put the price indicator in the first place, $4.6 \%$ of those interviewed put the design indicator in the first place and $7.7 \%$ of those interviewed put the advertising indicator in the first place. Regarding the degree of information of the population in relation to the promotion of aroma textiles on the Romanian market, $71.9 \%$ of the respondents believe that aroma textiles have not been sufficiently promoted. From the analysis of the amount that potential buyers would be willing to pay for an aroma therapeutic product, it turned out that most of those interviewed would be willing to pay less than 10 lei (2.2 Euro) for an antibacterial patch, between 50 lei (11.1 Euro) and 100 lei (22.2 Euro) for a flavoring sheet, between 100 lei (22.2 Euro) and 200 lei (44.4 Euro) for a flavoring sportswear and under 20 lei (4.4 Euro) lei for a pair of anti-cellulite tights. According to the obtained results, it was observed that people are willing to pay more (compared to the minimum amount proposed in the questionnaire) for flavoring sheet and flavoring sportswear, which shows that people feel the need for relaxation, and

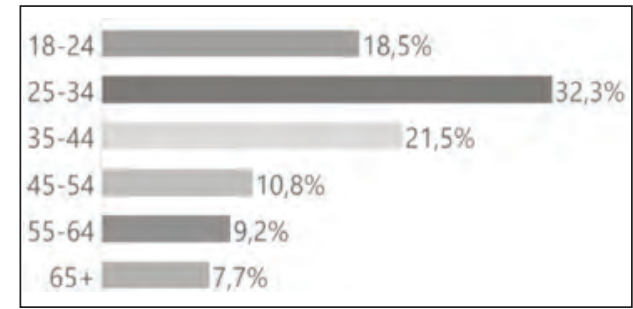

Fig. 1. Age of interviewees

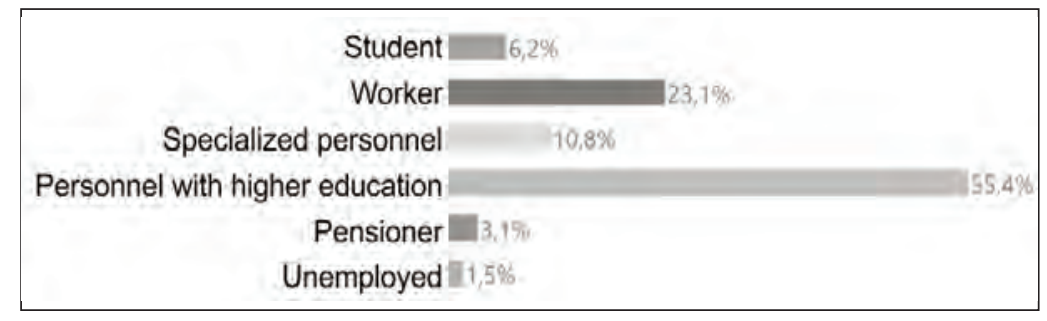

Fig. 2. Employment status of interviewees 
that they are willing to invest in products designed to help them manage stress.

\section{Study 2}

Research Hypothesis 1: Employment status influences the openness to the use of aroma textiles.

With the help of this hypothesis we will check if there exist differences in terms of openness to aroma textile products among respondents with different employment status.

To test this hypothesis the One Way Analysis of Variance (Anova) statistical method was used. According to the results of the analysis of variance (table 2), F, whose value is 3.501 is significant at the level of 0.0077 , since it is less than 0.05 .

Thus, the result obtained allows concluding that the employment status influences the openness to the use of aroma textiles. In conclusion, research hypothesis 1 was validated.

Research Hypothesis 2: Age influences the type of chosen product

The data from the One Way Analysis of Variance (table 3), $F(5,59)=0.293$ and $p=0.9150$, allow to conclude that age does not influence preference over a particular type of aroma textile product.
In conclusion, the research hypothesis 2 was not validated.

Research Hypothesis 3: Gender influences the criteria for choosing a product

According to the data presented in the Anova table (table 4) it follows that the gender variable does not influence the selection criteria of an aroma therapeutic product.

Report $F$ is insignificant at the level of 0.797 . In conclusion, research hypothesis 3 was not validated.

Research Hypothesis 4: The indicators: quality, price, design and advertising, are influenced by employment status

According to the results obtained from the analysis of hypothesis 4 (table 5), it was found that only the indicator "advertising" is influenced by employment status $[F(5,59)=2.754$ and $p=0.0266]$. Interesting is that people with higher education give a greater importance to the indicator "advertising" (11.1\% of them placed the advertising indicator on the first place, $19.4 \%$ - on the second place and $41.7 \%$ - on the third place).

In conclusion, research hypothesis 4 was partially validated.

\begin{tabular}{|l|r|r|r|r|r|c|}
\hline \multicolumn{7}{|c|}{ ONE WAY ANALYSIS OF VARIANCE FOR HYPOTHESIS 1 } \\
\hline & Sum of squares & \multicolumn{1}{|c|}{ df } & Mean square & F & p value & Eta squared \\
\hline Between groups & 7.836 & 5 & 1.567 & 3.501 & 0.0077 & 0.229 \\
\hline Within groups & 26.411 & 59 & 0.448 & & & \\
\hline Total & 34.246 & 64 & & & & \\
\hline $\begin{array}{l}\text { Homogenity } \\
\text { of variance }\end{array}$ & Levene & 0.310 & & & & \\
\cline { 2 - 9 } & p value & 0.9048 & & & & \\
\hline
\end{tabular}

Table 3

\begin{tabular}{|l|r|r|r|r|r|c|}
\hline \multicolumn{7}{|c|}{ ONE WAY ANALYSIS OF VARIANCE FOR HYPOTHESIS 2 } \\
\hline & Sum of squares & \multicolumn{1}{|c|}{ df } & Mean square & \multicolumn{1}{c|}{ F } & p value & Eta squared \\
\hline Between groups & 19.056 & 5 & 3.811 & 0.293 & 0.9150 & 0.024 \\
\hline Within groups & 767.498 & 59 & 13.008 & & & \\
\hline Total & 786.554 & 64 & & & & \\
\hline $\begin{array}{l}\text { Homogenity } \\
\text { of variance }\end{array}$ & Levene & 1.451 & & & & \\
\cline { 2 - 8 } & p value & 0.2195 & & & & \\
\hline
\end{tabular}

\begin{tabular}{|l|r|r|r|r|r|r|}
\hline \multicolumn{7}{|c|}{ ONE WAY ANALYSIS OF VARIANCE FOR HYPOTHESIS 3 } \\
\hline & Sum of squares & df & Mean square & F & p value & Eta squared \\
\hline Between groups & .037 & 1 & 0.037 & 0.067 & 0.797 & 0.001 \\
\hline Within groups & 35.501 & 63 & 0.564 & & & \\
\hline Total & 35.538 & 64 & & & & \\
\hline $\begin{array}{l}\text { Homogenity } \\
\text { of variance }\end{array}$ & Levene & 0.121 & & & & \\
\cline { 2 - 9 } & p value & 0.729 & & & & \\
\hline
\end{tabular}




\begin{tabular}{|l|r|r|r|r|r|c|}
\hline \multicolumn{7}{|c|}{ ONE WAY ANALYSIS OF VARIANCE FOR HYPOTHESIS 4 } \\
\hline & Sum of squares & \multicolumn{1}{|c|}{ df } & Mean square & F & p value & Eta squared \\
\hline Between groups & 10.781 & 5 & 2.156 & 2.754 & 0.0266 & 0.189 \\
\hline Within groups & 46.203 & 59 & 0.783 & & & \\
\hline Total & 56.985 & 64 & & & & \\
\hline $\begin{array}{l}\text { Homogenity } \\
\text { of variance }\end{array}$ & Levene & 1.378 & & & & \\
\cline { 2 - 8 } & p value & 0.2455 & & & & \\
\hline
\end{tabular}

For all hypotheses analyzed, Levene's test does not reject the assumption of equal variances $(p>0.05)$ that is required for ANOVA.

\section{CONCLUSIONS}

The results from marketing study shows that Romanians are increasingly interested in aroma therapeutic products, $63.1 \%$ of them have expressed interest in this kind of products. Although aroma textiles are not sufficiently promoted and people are becoming more and more aware of this fact $(71.9 \%)$, there has been a change in consumer preferences regarding the nature of textile products in recent years. Romanians are increasingly preferring textiles for health care, and this is evident from the results of the questionnaire. Most of the respondents place the greatest emphasis on the quality of the aroma therapeutic products $(76.9 \%)$, and much less on the presentation design of the product (7.7\%). Another aspect analyzed in the study was the choice of the type of aroma textiles from the ones presented. According to the results of the questionnaire, the highest weight is given by the flavoring patch with antibacterial and moisturizing effect (50.8\%), followed by: sportswear with a flavoring effect $(47.7 \%)$, sheets with a flavoring effect $(40 \%)$, tights with anticellulitic effect (35.4\%).

\section{ACKNOLEDGEMENTS}

This work was supported by a grant of the Romanian National Authority for Scientific Research and Innovation, CCCDI - UEFISCDI, project number 29/2018 COFUNDMANUNET III-AromaTex, project title "Manufacturing of value-added textiles for aromatherapy and skin care benefits", within PNCDI III.

\section{REFERENCES}

[1] Roshan, P., Functional finishes for textiles improving comfort, performance and protection, In: Woodhead Publishing Series in Textiles, 2015

[2] Zafar, N., Robin, S., Viennet, C., Humbert, P., Valour, J.P., Agusti, G., Fessi, H., Elaissari, A., Sponge like microparticles for drug delivery and cosmeto-textile use: Formulation and human skin penetration, In: International Journal of Pharmaceutics, 2017, 532, 1, 623-634, https://doi.org/10.1016/j.jpharm.2017.08.122

[3] Taieb, C., Mérhand, S., Bodemer, C., Methods of evaluation, in real life, of the wearing of a cosmeto-textile in the care of infants with atopic skins: Pilot study, In: Journal of the American Academy of Dermatology, 2019, 81, 4, AB94, https://doi.org/10.1016/j.jaad.2019.06.364

[4] Alonso, C., Martí, M., Barba, C., Lis, M., Rubio, L., Coderch, L., Skin penetration and antioxidant effect of cosmeto-textiles with gallic acid, In: Journal of Photochemistry \& Photobiology, B: Biology, 2016, 156, 50-55, https://doi.org/10.1016/j.jphotobiol.2016.01.014

[5] Martí, M., Martínez, V., Rubio, José L., Parra, L., Coderch, L., Antioxidant cosmeto-textiles: Skin assessment, Alonso, C., In: European Journal of Pharmaceutics and Biopharmaceutics, 2013, 84, 192-199, https://doi.org/ 10.1016/j.ejpb.2012.12.004

[6] Hossain, M.A., Benhaddou, A., Pagniez, F., Raymond, M., Le Pape, P., Simard, P., Théberge, K., Leblond, J., Econazole imprinted textiles with antifungal activity, In: European Journal of Pharmaceutics and Biopharmaceutics, 2016, 101, 137-144, https://doi.org/10.1016/j.ejpb.2016.02.003

[7] Rodríguez-Rojo, S., Varona, S., Núñez, M., Cocero, M.J., Characterization of rosemary essential oil for biodegradable emulsions, In: Industrial Crops and Products, 2012, 37, 137-140, https://doi.org/10.1016/ j.indcrop.2011.11.026

[8] Tülay, G., The role of microcapsules in masking bad odors of cotton fabrics, In: Industria Textila, 2017, 68, 4, 275-282, DOI: 10.35530/IT.068.04.1289

[9] Horrocks, A.R., Anand, S.C., Hand-book of Technical Textiles, Published by: Woodhead Publishing Limited in association with The Textile Institute, 2010

[10] Duhamela, N., Martin, D., Larcher, R., Fedrizzia, B., Barker, D., Convenient synthesis of deuterium labelled sesquiterpenes, In: Tetrahedron Letters, 2016; 57(40): 4496-4499 
[11] Dănilă, A., Zaharia, C., Şuteu, D., Mureşan, E.I., Lisă, G., Karavana, S.Y., Toprak, A., Popescu, A., Chirilă, L., Essential mint oil-based emulsions: Preparation and characterization, In: Industria Textila, 2019, 70, 1, 83-87, https://doi.org/10.35530/IT.070.01.1581

[12] Günaydin, K.G., Çeven, E.K., A research on tensile and abrasion properties of fabrics produced from conventional and fire resistant type polyester yarns, In: Industria Textila, 2017, 68, 6, 407-414, https://doi.org/10.35530/ IT.068.06.1484

[13] https://www.isensesolutions.ro/studiu-isense-solutions-romanii-din-ce-in-ce-mai-preocupati-sa-aiba-un-stil-deviata-sanatos/ [accessed 22 August 2019]

\section{Authors:}

\section{ANGELA DĂNILĂ ${ }^{1}$, EMIL IOAN MUREȘAN² ${ }^{2}$ ALINA POPESCU³ ${ }^{3}$ VLAD ROTARU1 ${ }^{1}$, CRISTINA ISTRATE $^{1}$}

1"Gheorghe Asachi" Technical University of lasi, Faculty of Industrial Design and Business Management, 29 Prof. Dr. Doc. Dimitrie Mangeron Blvd, 700050, lasi, Romania e-mail: angela.cerempei@yahoo.com; rotaruvlad1980@gmail.com; cristina.istrate@tuiasi.ro

2"Gheorghe Asachi” Technical University of lasi, Faculty of Chemical Engineering and Environmental Protection, 73 Prof. Dr. Docent D. Mangeron Blvd, 700050, lasi, Romania e-mail: eimuresan@yahoo.co.uk

${ }^{3}$ The National Research \& Development Institute for Textiles and Leather, 16 Lucretiu Patrascanu Str., 030508, Bucharest, Romania

e-mail: alina.popescu@incdtp.ro

Corresponding author:

ALINA POPESCU

e-mail: alina.popescu@incdtp.ro 